\title{
Introduction: After Bakke
}

There was the Sense of violation, of course. At the bidding of a governor anxious to ride the race issue to the White House, the Board of Regents of the University of California, against the opposition of faculty, students, and administration, over the vigorous protests of chancellors and demonstrators, voted to end affirmative action at the premier public institution of the nation's most demographically diverse state. ${ }^{1}$ The first major public university to do so. July 20, 1995.

At a stroke, the landscape of higher education had changed. Assumptions about race and ethnicity that had for decades guided policy were suddenly stripped of the armor of institutional inevitability. They were rent open, open to recuperation, revision, repudiation, whatever the newly emerging politics of a dawning era would decree. Stung by this eruption of history, the editors of Representations present this special issue devoted to exploring the new terrain.

Ironically, the University of California had itself helped to create the very legal framework that presently governs affirmative action within higher education. That framework was established in reaction to the University's defense of one of its own affirmative action programs to assist minority groups. The framework provides a clarifying lens for identifying the many questions of policy and principle that presently swirl through the maelstrom of the affirmative action controversy, for the law's tormented and equivocal response to affirmative action closely reflects the national debate.

After World War II, the equal protection clause of the Fourteenth Amendment of the United States Constitution came to be interpreted as strongly disfavoring the use of explicit racial or ethnic criteria by state institutions. ${ }^{2}$ This interpretation was part of the national effort to disestablish Southern apartheid. National egalitarian norms were also powerfully articulated by federal legislation. Most relevant to higher education, Title VI of the Civil Rights Act of 1964 prohibited "discrimination" on "the ground of race, color, or national origin" in any "program or activity receiving Federal financial assistance." The reach of Title VI remains quite broad; it applies to "all the operations of" any "college, university, or other postsecondary institution," any part "of which is extended Federal financial assistance," even to the minimal extent of enrolling "students who receive federal grants that must be used for educational purposes." ${ }^{.5}$ Affirmative action programs appeared to be in tension with these national norms of nondis- 
crimination. The first (and only) university affirmative action program to provoke a full-scale Supreme Court constitutional review of these legal constraints was that of the medical school of the University of California at Davis, which was subject to the restrictions of both the equal protection clause and Title VI.

A legal complaint challenging the program was filed on 20 June 1974, and it ultimately resulted in the decisive Supreme Court case of Regents of University of California v. Bakke. ${ }^{6}$ The Davis medical school had essentially reserved sixteen places out of an entering class of one hundred for persons who were members of one of four "minority groups": "Blacks," "Chicanos," "Asians," and "American Indians." The Court splintered badly in its evaluation of the case. Four justices wrote that the Davis program was a constitutional effort to redress the "effects of past societal discrimination," 8 and that Title VI "prohibits only those uses of racial criteria that would violate the Fourteenth Amendment if employed by a State or its agencies." ${ }^{\prime \prime}$ Four justices held that the program was illegal because Title VI requires a "colorblind" admission process in which "race" does not provide a "basis of excluding anyone from participation in a federally funded program." ${ }^{10}$ These justices did not address the independent restrictions of the equal protection clause.

The fifth and determinative vote was cast by Justice Lewis F. Powell Jr. Although Powell wrote for himself alone, his view carried the balance of power, and it has remained the governing law to this day. Over time, Powell's opinion has come to stand for four propositions: (1) Title VI applies constitutional standards. (2) The Constitution requires that all explicit state uses of racial criteria, whether or not for benign purposes, be subject to strict judicial scrutiny to determine whether they are narrowly tailored to serve compelling state interests. ${ }^{11}$ (3) The state's interest in remedying the generalized and systemic effects of societal discrimination is not compelling and hence cannot justify an affirmative action program. ${ }^{12}$ (4) The University of California's objective of attaining "a diverse student body" is constitutionally compelling and can justify the use of racial and ethnic criteria for admissions:

The atmosphere of "speculation, experiment and creation"-so essential to the quality of higher education - is widely believed to be promoted by a diverse student body. ... [I]t is not too much to say that the "nation's future depends upon leaders trained through wide exposure" to the ideas and mores of students as diverse as this Nation of many peoples.

Thus, in arguing that its universities must be accorded the right to select those students who will contribute the most to the "robust exchange of ideas," [the University of California] invokes a countervailing constitutional interest, that of the First Amendment. In this light, [the University] must be viewed as seeking to achieve a goal that is of paramount importance in the fulfillment of its mission. ${ }^{13}$

This last proposition provides the constitutional justification for contemporary university affirmative action programs throughout the country.

In explaining the objective of student "diversity," Powell made very plain that 
in his view the Constitution could not be read to accept a "diversity" that was defined solely by reference to differences between racial or ethnic groups. The "diversity" that Powell found constitutionally compelling was located instead in the infinitely variable differences among individuals, with respect to which racial or ethnic identity was only a "single although important element."14

The legal structure of the Davis medical school program established a fixed quota that automatically set aside sixteen slots for those who were members of four specific groups. The structure of the program thus collapsed the endless possibilities of difference into four discrete and limited categories of group identity. Powell found the Davis affirmative action program unconstitutional because it rendered race and ethnicity a determinative factor, rather than merely "a 'plus' in a particular applicant's file," a "plus" that would "not insulate the individual from comparison with all other candidates for the available seats." ${ }^{15}$ The Davis program was unconstitutional because it recognized only the diversity of racial and ethnic groups, rather than the diversity of individuals.

The crucial fact about Bakke, however, is that Powell did not end his judgment with a simple declaration of unconstitutionality. He took the unusual step of appending to his opinion the affirmative action plan of Harvard College, which Powell said he would find constitutional. The Harvard plan celebrated the diversity of individuals, but it also specifically noted that the value of ethnic and racial diversity could be attained only through an admission process that paid "some attention to numbers." 16

By stretching through dicta to approve the Harvard plan, Powell prospectively sanctioned affirmative action plans that went beyond the recognition of purely individual differences in order to ensure the representation of distinct racial groups. He thereby signified that "diversity" could not in fact be reduced to mere individual variety, but must also be understood to depend upon the effective presence of diverse group perspectives.

In dissent, Justices William Brennan, Byron White, Thurgood Marshall, and Harry Blackmun argued that the Davis and Harvard programs were functionally equivalent. "There is no sensible, and certainly no constitutional, distinction between, for example, adding a set number of points to the admissions rating of disadvantaged minority applicants as an expression of the preference with the expectation that this will result in the admission of an approximately determined number of qualified minority applicants and setting a fixed number of places for such applicants." 17 The only difference is that the Harvard program does not "make public the extent of the preference and the precise workings of the system while the Davis program employs a specific, openly stated number." 18 The dissent pressed a formidable functional logic.

Powell's opinion, however, was designed to work as an ideological construct, not merely as a functional one. Powell's ambition was to establish a fragile balance between, on the one hand, allowing academic affirmative action plans to continue 
as a means of redressing deep social dislocations and, on the other, ideologically destabilizing such plans so as to prevent their slide into a regime of racial and ethnic rights and entitlements. ${ }^{19}$ What was "immediately apparent to the public" was thus fundamental to Powell. ${ }^{20} \mathrm{He}$ was determined both to achieve a pragmatic accommodation to the social necessity of affirmative action and to extract a patent symbolic commitment to the values of individualism. ${ }^{21}$ In the process he crafted a remarkable judicial opinion whose "moderation and statesmanship," as Judge Henry Friendly observed, saved the country from "another Dred Scott." 22

The Regents' resolution of July 20 roughly repudiated Powell's delicate and judicious compromise. In truth, however, Powell's opinion had never been free from internal stress and attack. It had never silenced the contention that affirmative action ought to be used to remedy the present effects of past oppression. Such claims for explicit racial and ethnic rights to distributive justice, the implications of which extend beyond the limited context of university admissions and reach into the structure of the labor market, are visible in this special issue in the essays of Michael Rogin and Troy Duster; the clear suggestion of their argument is that the joint dissent in Bakke of Justices Brennan, White, Marshall, and Blackmun was correct. Moreover, by de facto sanctioning affirmative action programs based on race and ethnicity, the Bakke compromise has over the past two decades facilitated the demographic preconditions for the emergence of new claims for racial and ethnic entitlements based upon an aggressive identity politics that is both multicultural and separatist. These claims are traced and analyzed in the essays of Judith Butler and Michel Feher.

As evidenced in the Regents' resolution of July 20, the Bakke compromise also never fully satisfied those committed to the values of liberal individualism. ${ }^{23}$ These values, as illuminated by Jorge Klor de Alva, are deeply embedded within the American liberal and Christian traditions. They are not easily trespassed. In fact it is remarkable in retrospect how pervasive and entrenched affirmative action has become without previously having provoked the kind of frontal challenge represented by the Regents' resolution. No doubt this is in part due to the widespread recognition that racial and ethnic categories have throughout the centuries been employed as efficient categories of discrimination and oppression. The rough justice of affirmative action seems from this perspective undeniable. To comprehend the source of Powell's reservations, therefore, it is essential to understand the precise terms of the opposition he establishes in Bakke.

There are significant Western traditions-for example, Kantian and Christian traditions-in which the values of individual autonomy are understood as standing outside of history. But as Marianne Constable illustrates in her article in this special issue, it is all but impossible to deny either the historical construction 
or the historical salience of race as a relevant category of social diversity. Race leaches into the Regents' resolution despite their best efforts at exclusion. Anne Wagner makes the larger point that historical narratives of race resist suppression even by the most severe and seemingly apolitical efforts of cultural representation to do so.

Powell's opinion in Bakke, however, is not such an effort. He does not wish to deny history. The facets of individual diversity that he celebrates, for example, are all historically constructed. When Powell cites Harvard's praise for the diversity that comes from "city dwellers and farm boys; violinists and football players; biologists, historians, and classicists; potential stockbrokers, academics and politicians," ${ }^{24}$ he locates, as he must, individual diversity in historically given and contingent categories.

His opinion, therefore, does not rest upon an opposition to the historical construction of difference. It rests instead upon the historically grounded, normative, constitutional proposition that race and ethnicity ought not to be used as a ground of state action except in the rarest and most exceptional of circumstances. Powell strongly affirms this proposition in order to condemn the nation's history of official racial discrimination and oppression. So when Justice Blackmun, in his separate opinion in Bakke, notes the irony of the fact that universities "have given conceded preferences up to a point to those possessed of athletic skills, to the children of alumni, to the affluent who may bestow their largess on the institutions, and to those having connections with celebrities, the famous, and the powerful," ${ }^{25}$ he fails to engage Powell's central point, which is that when it comes to state action the country's history has made race and ethnicity special and problematic categories.

The question remains, however, how an ideal of racial nondiscrimination can be squared with an incontestable history of pervasive official misuse of racial and ethnic categories. The sociologist Niklas Luhmann astutely observes that normative propositions, unlike descriptive ones, are "capable of conformation as form by both conformable and deviant conduct." 26 Whereas we would be merely foolish steadfastly to maintain allegiance to descriptive hypotheses that prove frequently false, the same is not true of our moral commitments. Thus we do not ordinarily understand the commandment against murder to be rendered untenable by a high homicide rate. We are more likely to read the crime statistics as a reason to redouble our efforts to enforce the moral prohibition.

Similarly, a history of discrimination and oppression does not necessarily discredit the constitutional norm that a person's race and ethnicity ought not to matter to the state. It could lead us instead to even greater efforts fully to realize that liberal, individualist ideal. Of course the opposite outcome is also possible. We might come to believe that the ideal is so otherworldly, so pervasively irrelevant and compromised, as to be worthless as a guide to action, and we might demand 
that a different normative orientation be adopted. Or we might believe that the ideal should be compromised or temporarily suspended in the service of its realistic fulfillment.

The debate over the ideal can have many different possible outcomes. It is clear, however, that the debate will turn on a wide variety of practical, historical, and contingent considerations. It is at this juncture of the argument that the sociological and demographic analyses offered in this special issue by Richard Walker become relevant, as do the assessments of political and strategic factors contributed by David Hollinger, as do the personal and experiential reflections recorded by Barbara Christian.

The crude inconsistency between the ideal of racial nondiscrimination and the fact of racial oppression is most often finessed in liberal thought by confining affirmative action to a discrete and bounded temporal position. Affirmative action, it is said, is necessary as a temporary expedient to overcome past discrimination. In the famous words of Justice Blackmun in Bakke, "In order to get beyond racism, we must first take account of race." ${ }^{27}$

Powell's opinion, however, does not take this tack. It instead invokes benefits of diversity that are not represented as temporary. These benefits are figured as structural and atemporal. Of course Powell views these benefits as merely permissive; nothing in his opinion compels universities to seek them, nor does he attempt to define the terms in which they must be embodied. Nevertheless, over time $B$ akke has come to stand for the proposition that race and ethnicity are constitutive of a structural and atemporal value of diversity. This notion of diversity has in turn fostered the paradoxical tendency to view the categories of race and ethnicity as themselves immune from the contingencies of historical construction. Essays in this special issue by Miranda Oshige McGowan, Rachel Moran, and Michael Omi and Dana Takagi explore the costs and difficulties of this problematic tendency. At stake are exceedingly important considerations in the practical design of affirmative action programs under Bakke.

Whatever the deficiencies of Powell's opinion in Bakke, and no doubt they are legion, it has always seemed to me to contain two shining virtues. The first is its effort to justify affirmative action on the basis of the "mission" of higher education. Powell resists characterizing affirmative action as unrelated to educational purposes and hence as externally imposed upon universities and colleges. The strength of his approach is now especially apparent, as faculty throughout the University of California system mobilize to resist the Regents' resolution on the grounds that it is an improper political imposition on the educational mission of the University. ${ }^{28}$ There are signs that defending the institutional autonomy of public universities may become of increasing national importance as "a new group 
of public-college trustees" appears poised to move "aggressively" to implement far-reaching political "agendas." ${ }^{9}$

Partisans for affirmative action have sometimes, in the heat and intensity of the controversy, failed to appreciate the importance of this point. One can occasionally discern resonances of the highly nihilistic claim that affirmative action ought to be unproblematic because university admissions criteria are arbitrary, so that the refusal to extend preferences based upon racial or ethnic identity is merely discriminatory or unjust. Those concerned to unmask "the myth of merit" and to expose the "subjective nature of university decisions" are particularly attracted to this line of argumentation. ${ }^{30}$

A major problem with this perspective, however, is that it ultimately denies legitimacy to the distinctive educational purposes of institutions of higher learning. If universities and colleges have no particular mission, there can be no principled objection to the Regents' subordination of the University of California to the presidential ambitions of the State's governor. But if, on the contrary, there are ends to which higher education ought to aspire, then "merit" in the admission process will be neither mythical nor subjective, but will represent instead the standards of selection best suited for the attainment of those ends. ${ }^{31}$

I do not mean to imply that higher education has any single or simple set of purposes. No doubt the ends of colleges and universities are diverse and various, which is why most colleges and universities employ multifarious measures of merit embodied in complex and seemingly inconsistent standards of admission. Many, if not most, of the goals of higher education are probably best expressed in standards of admission that are neutral with respect to racial and ethnic identity. But this is not the case with respect to all such possible goals.

The institutional autonomy of public universities may best be protected if the issue of affirmative action is addressed in terms of the question of appropriate and inappropriate educational purposes. In Bakke, for example, Powell advanced the theory that learning was an appropriate object of higher education and that learning would be improved through a "wide exposure' to the ideas and mores of students as diverse as this Nation of many peoples." Powell concluded that admission standards could legitimately acknowledge racial and ethnic differences because that acknowledgment was necessary in order to realize the benefits of diversity. While the heuristic premises of Powell's theory are surely subject to debate, it is at least the right kind of debate to be having in the context of affirmative action.

It is important to recognize, however, that the heuristic value of diversity is not the only theory of higher education that would justify standards of admission that acknowledge racial and ethnic differences. In the remainder of this introduction I would like briefly to sketch a different such theory: the creation of a democratic public culture. 
Democracy and public education have long been regarded as inseparably complementary. Democracy is the practice of collective self-determination; public education is an investment by the state to disseminate the training and knowledge prerequisite for that practice. The question I wish to analyze concerns the distinctive contribution of public higher education to democratic practice. The question will, I hope, illuminate what I regard as the second great strength of Powell's opinion in Bakke, which is its accommodation of affirmative action within a justificatory framework that unsettles the slide toward group rights and entitlements.

"The essence of democracy," writes Jean Piaget, "resides in its attitude towards law as a product of collective will, and not as something emanating from a transcendent will or from the authority established by divine right. It is therefore the essence of democracy to replace the unilateral respect of authority by the mutual respect of autonomous wills." 32 Democracy, we might more precisely say, entails the perpetual process of reconciling the self-determination of autonomous wills with the collective self-determination of a polity. This process, which is perennially open-ended, occurs through the medium of a public discourse sustained by a public culture. ${ }^{33}$

Two consequences flow from this formulation. First, there is a strong affiliation between democracy and individualism, because the autonomous wills of individuals are conceptualized as politically prior to and constitutive of the rights of groups. If this were not the case, if the self-determination of individuals were to be subordinated to the identities and norms of particular groups, the possibilities of collective self-determination would to that precise extent be circumscribed.

Second, because of this political individualism, democratic public culture must also be understood as distinct from the cultures of particular groups and communities. Even though we know that in actuality the identities of individuals are formed through socialization into the mores of specific and historical groups and communities, the ideal of self-determination requires that public culture always maintain the possibility of citizens imagining themselves as something other than what they in fact are. Public culture must be large enough to encompass this possibility and therefore to embrace all possible groups and communities. Public culture is, as Thomas Keenan writes, the "realm . . of others, of all that is other to-and in-the subject itself." ${ }^{34}$

Historically and sociologically, public culture typically evolves from "cultural differentiation"; it functions, as the sociologists tell us, as a "universe of discourse" within which distinct communities can nevertheless come together to form a single democratic polity. ${ }^{35}$ Public culture appears as a site of difference, in which communication occurs between those who do not share the identity and assumptions that define distinctive communities. Successful participation in public culture therefore requires a special form of cultural capital: the ability to interact in a "critical" ${ }^{36}$ manner that establishes distance from local certitudes and thereby creates the possibility of spanning the boundaries between disparate groups. 
Institutions of higher education are today a primary source of that cultural capital. They aspire to cultivate the remarkable and difficult capacity to regard oneself from the perspective of the other, which is the foundation of the critical interaction necessary for active and effective citizenship. ${ }^{37}$ The cultivation of this capacity is especially important for public universities, for they are in part created to educate generations of future citizens so as to maintain the legitimacy of democratic self-government. Public universities have the educational obligation to dispense the cultural capital at their disposal in a manner that accounts for the health of public culture.

There are many dimensions to this obligation, but certainly one aspect of it would entail facilitating participation in public culture by members of politically salient communities. A political culture without such participation would be neither democratic nor healthy, but merely repressive. In the United States, and especially in California, racial and ethnic identities mark lines of intense political division. If the racial and ethnic rifts that divide us are to be transcended by a democratic state that is legitimate to all sides, there must be articulate participation in public culture that concomitantly spans the lines of these controversies. I would argue, therefore, that the educational mission of the University of California ought to include the obligation to facilitate this participation.

If "normal" admission standards, by which I mean admission standards formulated to achieve other educational goals of the University, would in effect operate so as to exclude members of politically salient racial and ethnic communities, then the University's obligation to promote a flourishing public culture may well require standards of admission that explicitly recognize racial and ethnic identity. The justification of these standards would not depend upon any theory of group rights or entitlements; it would not reflect the extrinsic goal of compensating for past wrongs or oppression; it would not rely upon any pedagogical theory of the heuristic value of diversity. It would flow instead from the educational goal of fostering the public culture upon which rests the success of democratic selfgovernance. It would follow from the perception that in the United States today democratic legitimacy very much depends upon the active participation of an educated and critical citizenry that spans existing racial and ethnic differences.

Because this goal would conceptualize university applicants as potential citizens who are capable of transcending local attachments and identities, it would entail admission standards that, like those proposed by Powell in Bakke, ideologically privilege the individuality of applicants. This means that racial and ethnic identity would be relevant, but not determinative. An admissions policy based upon the goal of nurturing public culture would thus retain Powell's pragmatic accommodation between a symbolic commitment to individualism and a practically effective response to social dislocation.

It is uncertain whether this justification for affirmative action, if candidly expressed, would pass constitutional muster. But the primary purpose of this special 
issue is to think frankly among ourselves, rather than to speculate about the constitutional interpretation of nine justices. Our fundamental challenge is to decide what we wish to accomplish politically and how we wish to accomplish it, and we may hope that in the end constitutional law will follow the lead of informed judgment.

\section{Notes}

1. The Regents resolved that "effective January 1, 1997, the University of California shall not use race, religion, sex, color, ethnicity, or national origin as criteria for admission to the University or to any program of study." The complete text of the Regents' resolution appears in an appendix on page 184. The Regents' prohibition against the use of the criteria of religion and sex raises important questions that we do not address in this special issue.

2. "Nor shall any State ... deny to any person within its jurisdiction equal protection of the laws." U.S. Constitution, amend. 14, sec. 1.

3. Civil Rights Act of 1964, U.S. Code, vol. 42, sec. 2004 (1994).

4. Civil Rights Restoration Act of 1987, U.S. Code, vol. 42, sec. 2000d-4a (1994).

5. Grove City College v. Bell, 465 U.S. 555, 558 (1984).

6. Regents of University of California v. Bakke, 438 U.S. 265 (1978). For an account of the case, see Bernard Schwartz, Behind Bakke: Affirmative Action and the Supreme Court (New York, 1988).

7. Regents v. Bakke, 274.

8. Ibid., 362 (joint opinion of Justices William Brennan, Byron White, Thurgood Marshall, and Harry Blackmun).

9. Ibid., 328 .

10. Ibid., 415-18 (opinion of Justice John Stevens). Stevens's opinion was joined by Justices Warren Burger, Potter Stewart, and William Rehnquist.

11. Lewis F. Powell's actual formulation of the strict scrutiny test was somewhat different. See ibid., 305. For a modern formulation of the strict scrutiny test, see Adarand Constructors $v$. Pena, 115 Sup. Ct. 2097, 2113 (1995). On the influence of Powell's opinion in Bakke for modern equal protection doctrine, see ibid., 2108-12.

12. Powell conceded the importance of the State's interest in "ameliorating, or eliminating where feasible, the disabling effects of identified discrimination," but he contended that societal discrimination was by its very nature general and amorphous. Regents $v$. $B a k k e, 307$. Powell was not prepared to accept a rationale for affirmative action that he believed would cede to "all institutions throughout the Nation" the power to use racial criteria "at their pleasure" to establish affirmative action programs to assist "whatever groups are perceived as victims of societal discrimination." Ibid., 310. The modern Court has explicitly adopted this position. See Richmond v. J. A. Croson Co., 488 U.S. 469 (1989); Wygant v. Jackson Board of Ed., 476 U.S. 267 (1986).

13. Regents v. Bakke, 311-13.

14. Ibid., 315-19. For a discussion of the two different kinds of diversity, see Robert Post, "Cultural Heterogeneity and Law: Pornography, Blasphemy, and the First Amend- 
ment," in Constitutional Domains: Democracy, Community, Management (Cambridge, Mass., 1995).

15. Regents v. Bakke, 317.

16. Ibid., 323 . 17. Ibid., $378 . \quad$ 18. Ibid., 379.

19. For a good discussion of Powell's intentions, see John C. Jeffries Jr., Justice Lewis F. Powell, Jr. (New York, 1994), 455-501.

20. "There is no basis for preferring a particular preference program simply because in achieving the same goals that the Davis Medical School is pursuing, it proceeds in a manner that is not immediately apparent to the public." Regents $v$. Bakke, 379 (joint opinion of Brennan, White, Marshall, and Blackmun).

21. The present Court is now also engaged in extracting a symbolic commitment to individualist values, in the context of a pragmatic adjustment to racial realities, in the area of reapportionment plans designed to maximize minority representation. Compare Miller v. Johnson, 115 Sup. Ct. 2475 (1995) with De Witt v. Wilson, 115 Sup. Ct. 2637 (1995). As the Court stated in Shaw v. Reno, 113 Sup. Ct. 2816, 2827 (1993), the first of these cases, "reapportionment is one area in which appearances do matter." By contrast, the Court's enforcement of individualist values in the area of employment has not at all been merely symbolic. See Richmond v. J. A. Croson Co., 488 U.S. 469 (1989).

22. Quoted in Jeffries, Justice Lewis F. Powell, Jr., 498.

23. Indeed, as I write this introduction, a panel of the United States Court of Appeals for the Fifth Circuit has just struck down an affirmative action plan based upon the rationale of Bakke at the Law School of the University of Texas at Austin. The Court held that Powell's "lonely opinion in Bakke" should no longer be regarded as controlling precedent because intervening Supreme Court cases stand for the proposition "that any consideration of race or ethnicity by the law school for the purpose of achieving a diverse student body is not a compelling interest under the Fourteenth Amendment." Hopwood v. Texas, 1996 U.S. App. LEXIS 4719 (5th Cir. 18 March 1996), 32, 40. The Court observed that "diversity fosters, rather than minimizes, the use of race. It treats minorities as a group, rather than as individuals." Ibid., 40.

24. Regents v. Bakke, 322.

25. Ibid., 404.

26. Niklas Luhmann, Risk: A Sociological Theory, trans. Rhodes Barrett (New York, 1993), 55. For a full elaboration of the point, see Niklas Luhmann, A Sociological Theory of Law, trans. Elizabeth King and Martin Albrow (Boston, 1972), 31-35.

27. Regents v. Bakke, 407.

28. See, e.g., "Depoliticizing UC," Sacramento Bee, 15 January 1996, B6.

29. Patrick Healy, "The Republican Contract with Higher Education: Activist Trustees Raise Questions on Finances, Curriculum, Racial Preferences," Chronicle of Higher Education, 26 January 1996, A26.

30. Martha S. West, "Gender Bias in Academic Roles: The Law's Failure to Protect Women Faculty,” Temple Law Review 67 (1994): 134-43.

31. See Kenneth L. Karst and Harold W. Horowitz, "Affirmative Action and Equal Protection," Virginia Law Review 60 (1974): 961-63; Richard H. Fallon Jr., "To Each According to His Ability, from None According to His Race: The Concept of Merit in the Law of Antidiscrimination," Boston University Law Review 60 (1980): 864-76. If in fact the ends of higher education cannot be advanced by any selection criteria, a most unlikely hypothesis, then a lottery may perhaps be the fairest process of admission.

32. Jean Piaget, The Moral Judgment of the Child, trans. Marjorie Gabain (New York, 1948), 366. 
33. The argument of this and the subsequent two paragraphs is fully developed in Post, Constitutional Domains, 134-96.

34. Thomas Keenan, "Windows: of Vulnerability," in Bruce Robbins, ed., The Phantom Public Sphere (Minneapolis, Minn., 1993), 133.

35. Carroll D. Clark, “The Concept of the Public," Southwestern Science Quarterly 13 (1933): 311-15. See Robert E. Park and Ernest W. Burgess, Introduction to the Science of Sociology (Chicago, 1924), 254; Kenneth Ewart Boulding, The Image: Knowledge in Life and Society (Ann Arbor, 1956), 137-47.

36. Alvin W. Gouldner, The Dialectic of Ideology and Technology: The Origins, Grammar, and Future of Ideology (New York, 1976), 98.

37. For a classic and eloquent statement of this position, see Wieman v. Updegraff, 344 U.S. 183, 194 (1952) (Frankfurter, J., concurring). 